<原 著 $>$

硬変肝の部分切除後における肝細胞の再生機序に関する検討

猪口 正孝****渋谷 哲男庄司佑* 浅野 伍朗**

要 旨: Thioacetamide 投与ラット硬变肝を用い $2 / 3$ 肝切除後における細胞, 細胞外基質と 増殖因子の動態について形態学的，免度組織化学的に観察し検討した．肝切除の 7 日後に類洞 の開大と Kupffer 細胞の増殖， 3 週後に類洞の狭小化，5 週後には類洞の再開大と Kupffer 細

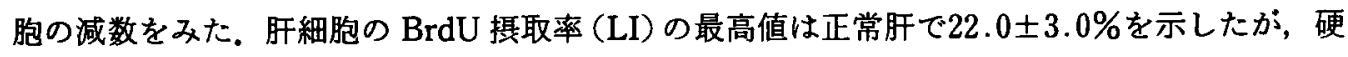
変肝では12.3土1.7\%にとどまった，S 期細胞の分布は正常肝で讱緑部と中心部に差異があり， 硬変肝では偽小葉内に不規則な局在を示した。增殖因子の bFGF，EGF は硬変肝で不均一に分 布し，TGF及1は硬変肝では持続的な局在を示した。細胞外基質では I・III・IV型コラーゲン， ラミニン,フィブロネクチンの局在に肝切除前後で著变を認めなかった。 以上より, 硬変肝で は細胞外基質に著変はなく血行動態の変化に上る增殖因子の非効率的供給と TGF $\beta 1$ 等の增殖 抑制因子の持続的存在により，肝細胞の增殖能が減弱していると考兄られた。

来引用語：肝硬変 肝再生 細胞動態 增殖因子 細胞外基質

\section{緒言}

臨床的にも硬变肝における部分切除後の残存肝の細 胞增殖が正常肝に比べて著しく不良であることが知ら れている. 肝藏の再生には Hepatocyte Growth Factor (HGF) ${ }^{1,2)}$, Transforming Growth Factor $\alpha$ $(\mathrm{TGF} \alpha)^{3)}$, basic Fibroblast Growth Factor $(\text { bFGF })^{4)}$, Epidermal Growth Factor (EGF) ${ }^{3.5}$ 等の 増殖因子ゃ増殖抑制因子である Transforming Growth Factor $\beta$ (TGF $\beta$ ) の関与-8)，さらには Kupffer 細胞等の類洞壁細胞とHematolymphoid system"の働きが注目されている。しかしこの肝缄の 再生能の低下ゃ機序については未だ不明な点も多く, その解明が必要とされている.ここに Thioacetamide （以下 TAA）投与による実験的硬変肝モデルを作成 し，その後 Higgins \& Anderson 法 $^{101} に よ り$ 約70\%の 広範囲の肝部分切除を行い，肝葴における肝細胞や類 洞壁細胞の増殖とそれに関与する各増殖因子、増殖抑 制因子ゃ細胞外基質の動態について免疫組織化学的手 法を用いて検討した。

\section{対重およU実験方法}

1. 対象：8週龄 Wistar 系雄性ラット $(200 ２ 50 \mathrm{~g})$ （埼玉実験動物供給所）を用いた。

- 日本医科大学外科学第 2 講座

**同 病理学第 2 諈座

《受付日1993年10月12日>

\section{2. 実験方法}

A : 硬变肝の作成

1） 36 匹のラットに $4 \% \mathrm{TAA} 200 \mathrm{mg} / \mathrm{kg}$ を週 3 回, 7 週間連続的に腹腔内に投与し訮硬変を作成し ${ }^{11,12)}$, 5 週間休薬した後下記の手術を行った。

2) 対照の TAA 非投与ラット36匹には 7 週間生理 的食塩水を投与し， 5 週間放置の後同様の手術を行。 た。

\section{B：硬変肝の部分切除術（以後肝切除）}

上記の条件下の肝缄は Higgins \& Andersonの方 法 ${ }^{101} 3$ 分の 2 を部分切除し切除標本を得た。切除後 一旦閉腹，その後 $1 \cdot 3 \cdot 6 \cdot 12 \cdot 24$ 時間・ 3 日・ 7 日・ 3 週・ 5 週後に各 4 匹ずつ再び開腹し肝䁍を摘出し, 摘出標本を得た。切除標本と摘出標本（右葉と尾状葉） は最大割面にて分割し，10\%中性ホルマリン液を用い て固定後パラフィン包埋し，薄切後，H \& E, Pap, AZAN 染色を施行し, 形態学的な变化を観察すると共 に以下の免疫組織化学的手法により検索を行った.

$C:$ 観察方法

1) 細胞動態の観察

$\mathrm{S}$ 期細胞がチミジンの analogueである Bromodeoxyuridine (BrdU) を核内に取り込むた $め^{13)}, \mathrm{BrdU}(50 \mathrm{mg} / \mathrm{kg})$ を肝摘出 1 時間前に投与した. 摘出標本ではBrdUのモノクローナル抗体（Sigma 社）を用いて $\mathrm{ABC}$ 法により免度組織化学的手法に上 
クその摂取率を検討した，肝細胞では，小葉の中心帯 （中心静脈域)之辺縁部 (門脈域)に分けそれぞれ 1,000 個の肝細胞の中の BrdU 標識細胞を数点て LI を算出 した. たたし硬変肝に関しては偽小葉の辺縁部と中心 部に分けて算出した。 また，小葉内の肝非実質細胞(類 洞壁細胞)と，線維化巣の細胞についても同様に LI を 算出した ${ }^{(4)}$.

2) 免疫組織化学的観察

bFGF，EGF の増殖因子と TGF $\beta 1$ の増殖抑制因子 さらに I ・III・IV型コラーゲン, ラミニンの細胞外基 質に関しては, $3 \mu$ のパラフィン切片を作成し, 脱パラ フィン，脱水後には $0.3 \% \mathrm{H}_{2} \mathrm{O}_{2}$ 加メタノールで内因性 ペルオキシダーゼを除去した後に avidin-biotinperoxidase-complex (ABC) 法にて染色した， 1 次抗 体としてウサギ・抗ヒト EGF 抗体 (Oncogene 社)，ウ サギ・抗ウシ bFGF 抗体 (Sigma 社), こワトリ・抗ヒ 卜 TGF $\beta$ 1抗体 (King Brewing 社) の各ボリクローナ ル抗体そしてヤギ・抗ヒトI型コラーダソ抗体 (Southern 社)，ヤギ・抗ヒトIII型コラーゲン抗体 (Southern 社)，マウス・抗ヒトIV型コラーゲン (Shiseido 社), マウス・抗ヒトラミニン抗体 (E-Y Lab.), の各モノク ローナル抗体を用いた。希釈倍率は抗 EGF 抗体は200 倍, 抗 bFGF 抗体は 3,000 倍, 抗 TGF $\beta$ 1抗体は 500 倍, 抗 I・III型コラーゲン抗体と抗ラミニン抗体で200倍, また抗IV型コラーゲン抗体は100倍としそれぞれ 4 " C overnight で反応させた。

またフィブロネクチンに関しては $3 \mu$ のパラフィン 切片を作成し, 脱パラフィン, 脱水後に $0.3 \% \mathrm{H}_{2} \mathrm{O}_{2}$ 加 タノールで内因性ペルオキシダーゼを除去した後にウ サギ・ポリクローナル抗ヒト・フィブロネクチン抗体 （Dako 社）を用いて間接法にて染色を行った。

3）間質量の測定

切除標本と肝切 5 週間後の摘出標本に AZAN 染色 を行い, 膠原線維面積をLuzex 3画像解析装置 (Nireco 社）を用いて形態計測を行った。

\section{結果}

\section{1. 形態学的観察}

肝切前の肝臓変化：切除標本では薄くなった線維性 隔壁により偽小葉が形成され，ヒ上乙型肝硬変症に類 似した形態変化がみられ，TAA 投与期間中にみられ た cholangiofibrosis と言われる細胆管の堌生は見ら れなかった。 また piecemeal necrosis はなくグリンン 䩗の限界板は保たれ炎症性変化は軽度で小葉内にも著 明な资症像は観察されなかったが，Kupffer 細胞等の

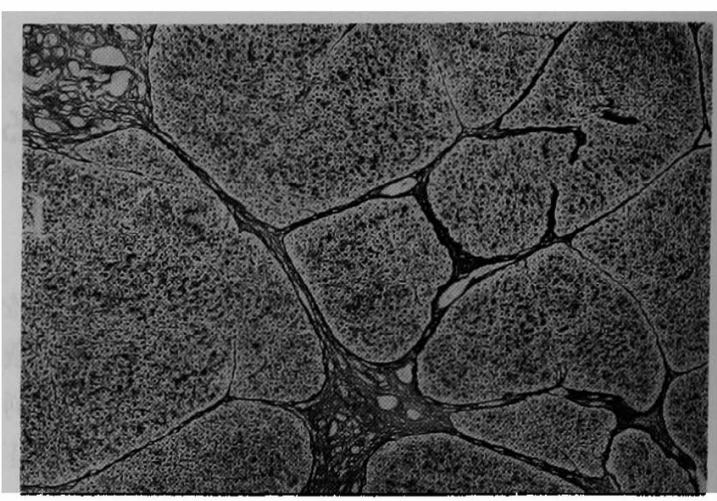

Fig. 15 weeks after 70\%-partial hepatectomy, histological feature of cirrhotic liver. Pap stain. $(\times 10)$

間葉系細胞の增殖は認められた。

肝切後の肝臓変化：肝硬変の形成が確認された後部 分的に切除を行ったか，その後の各再生期間を経過し た摘出標本では最長の 5 週後まで偽小葉の形成がみら れ肝硬変の形成が確認された。単位面積あたりの間質 面積の割合は切除標本で $6.7 \pm 1.5(\mathrm{~m} \pm \mathrm{S}) \%$, 肝切 5 週間後の摘出標本では $5.8 \pm 1.3 \%$ あり湿著な差異は 認められなかった．線維化巣内には切除標本と比較し 著変はなかった (Fig. 1)．小葉内では24時間後には肝 細胞の細胞質の染色性が粗になり, balooning を認め た. 3 日後には肝細胞の染色性は回復したが, 類洞の 開大が顥著となった。7日後には開大した類洞内に Kupffer 細胞やリンパ球の増殖が顕著にみられた，3 週後には類洞は㹟小化し偽小葉内の肝細胞の密度も高 くなり, Kupffer 細胞の腫大がみられた。 5 週後には訮 細胞の萎縮と共に類洞が開大し, Kupffer 細胞やリン バ球の数にも減少がみられた。 上記の変化は正常肝に おいても認められるが，硬変肝においては肝細胞の大 小不同性や，染色性の不均一性が著明であった，しか し Kupffer 細胞等の類洞壁細胞やリンパ球の経時的 推移には正常肝と比較して著明な差異は認められな かった。

\section{2. 各細胞の BrdU 摂取率}

肝細胞の LI をみると正常肝では 6 時間後に最低値 を示し，24時間後で22.0\%と最高值を示した（Fig. 2a)，一方硬変肝では 6 時間後には摂取細胞はほとん ど観察できなくなり LIは最低値を示し，24時間後に はピークの12.3\%に達した $(\mathrm{p}<0.005)$ (Fig. 2b)，そ して 3 日後には LIは再び低下し $0.7 \%$ となり，以後 5 


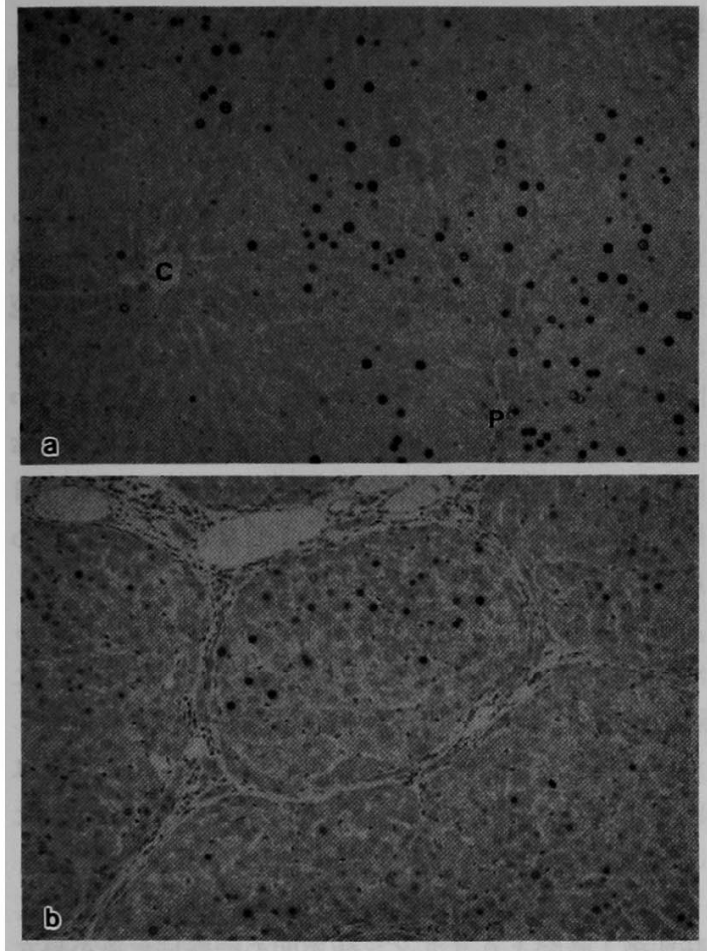

Fig. 2 Localization of BrdU positive hepatocytes 24 hours after partial hepatectomy. a: Normal liver. BrdU positive hepatocytes localized in portal zone through central zone of hepatic lobules. b: Cirrhotic liver. BrdU positive hepatocytes irregularly localized in pseudo-lobules $(\mathrm{a}, \mathrm{b} \times 50)$

週目までほぼ同様の値で推移した（Fig. 3)。

類洞壁細胞では正常肝において肝切 3 日後に $7.2 \%$ の最高值を示し，以後著変はなく全期間を通じて硬変 肝に比べて低值を示した。，一方硬変肝における壁細胞 の LI は約 $2 \% て ゙ 12$ 時間後まで推移し，24時間後には $0.3 \%$ と最低値を示した. 肝切 3 日後には $8.3 \%$ 最高 値を示したが， 7 日目以後は約 $2 \%$ の值を維持してい た (Fig. 4).

線維化巣内にみられる細胞の LI は24時間後で類洞 壁細胞の LI とともに最低值となり， 3 週間後には最 高値を示したが，ばらつきもあり全期間を通して 2 〜 3\%の範囲で推移していた（Fig. 5).

また Brdu摄取細胞の局在よりみると24時間後の BrdU 撕取肝細胞では正常肝の門脈域で37.5\%，中心 静脈域で $5.6 \%$ LIに差がみられた。一方硬変肝では 偽小葉の辺縁帯で12.2\%，中心部で18.2\%と僅かなが

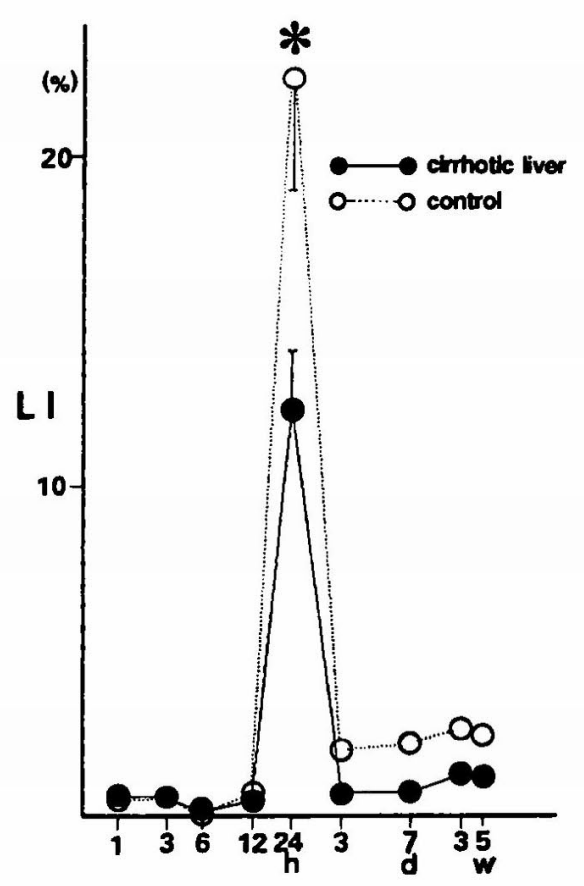

Fig. 3 Sequential changes of LI of hepatocytes after partial hepatectomy. Statistically significant difference from control value. ${ }^{*} p<0.005$

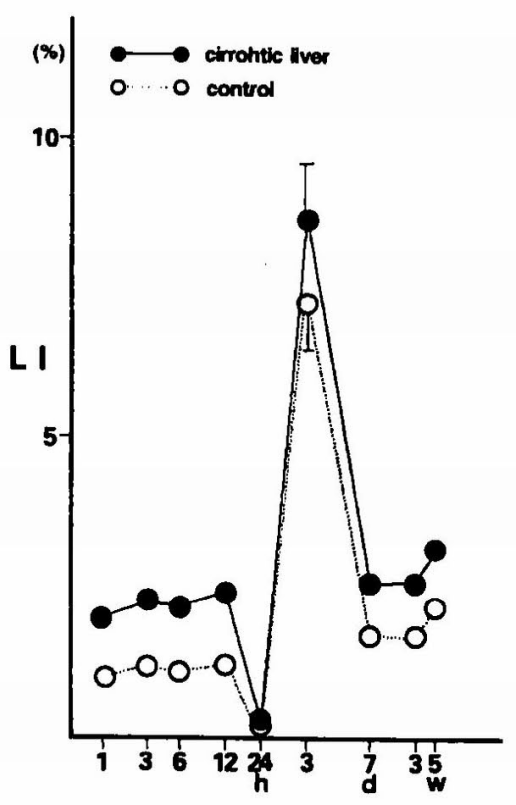

Fig. 4 Sequential changes of LI of parasinusoidal cells after partial hepatectomy. 
ら中心部で高率であったが, 有意の差は認めなかった。

類洞壁細胞では硬変肝と正常肝で共に辺緣帯, 中心 帯における差はなく BrdU摂取細胞は小葉内に一様

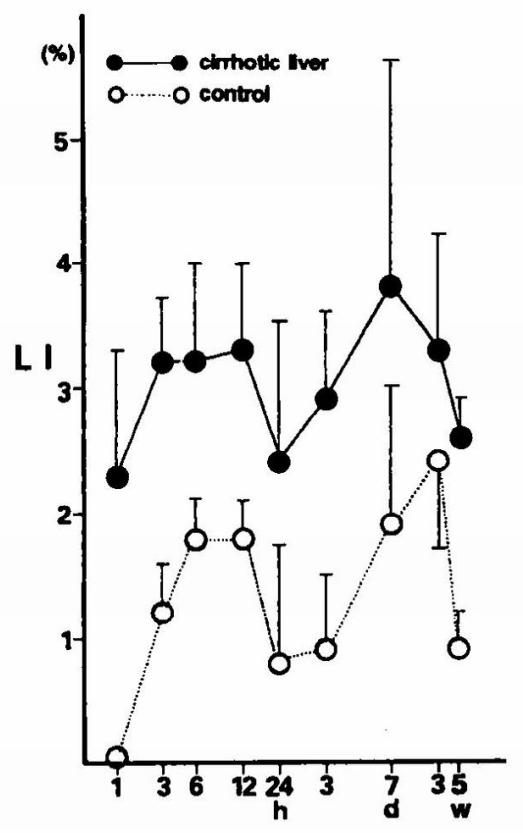

Fig. 5 Sequential changes of LI of mesenchymal cells in fibrous septums after partial hepatectomy.
に局在していた.

硬変肝の線維化巣内では局所的に集簇して胆管細胞 や血管内皮細胞に BrdU の㠌取が認められた。

\section{3. 增殖因子と增殖抑制因子の局在}

bFGF：正常肝の切除標本には局在を認めなかっ た. 摘出標本では訮切 1 時間後の肝細胞の細胞質と核 に局在を認め門脈域のグリンン鞘周囲に陽性細胞を認 めたが, 中心静脈域ではその局在が認められなかった。 bFGF 陽性細胞は 3 時間, 6 時間, 12時間後と徐々に中 心静脈域にその局在が広がり，24時間後には小葉全体 にbFGF 陽性細胞が認められた（Fig. 6a）. 以後 3 日 後までは局在に変化はないが，7 日後には局在は認め られなくなった。

硬変肝の切除標本の肝細胞には局在を認めなかっ た. 摘出標本では肝切後 1 時間で偽小葉内に不規則に 陽性細胞を認めた。陽性肝細胞は24時間後まで増加し たが，陰性細胞の混在も多数認められた，7日以後は 正常肝と同様にほとんどその局在を認めなかった (Fig. 6b).

$\mathrm{EGF}$ ：正常肝の切除標本には局在を認めなかった。 肝切後 1 時間よりグリンン鞘周囲の門脈域にその局在 が認められはじめ，24時間後まで中心静脈域に向かっ て暫増し，3日後までは小葉全体に認められた７日 後以後は認められなくなった（Fig. 7a).

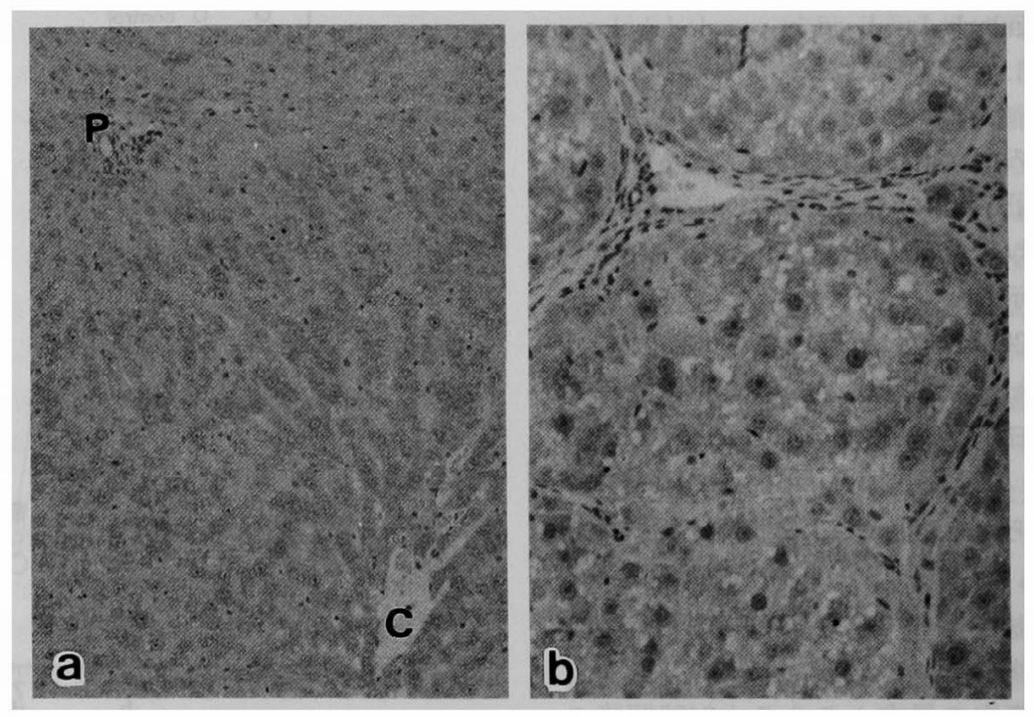

Fig. 6 Localization of basic-FGF positive hepatocytes 24 hours after partial hepatectomy. a : Normal liver. b-FGF positive hepayocytes localized in central and middle zone. $\mathrm{b}$ : Cirrhoic liver. $\mathrm{b}$-FGF positive hepatocytes were irregularlyd detected in pseudolobules. $(\mathrm{a} \times 25, \mathrm{~b} \times 50)$ 


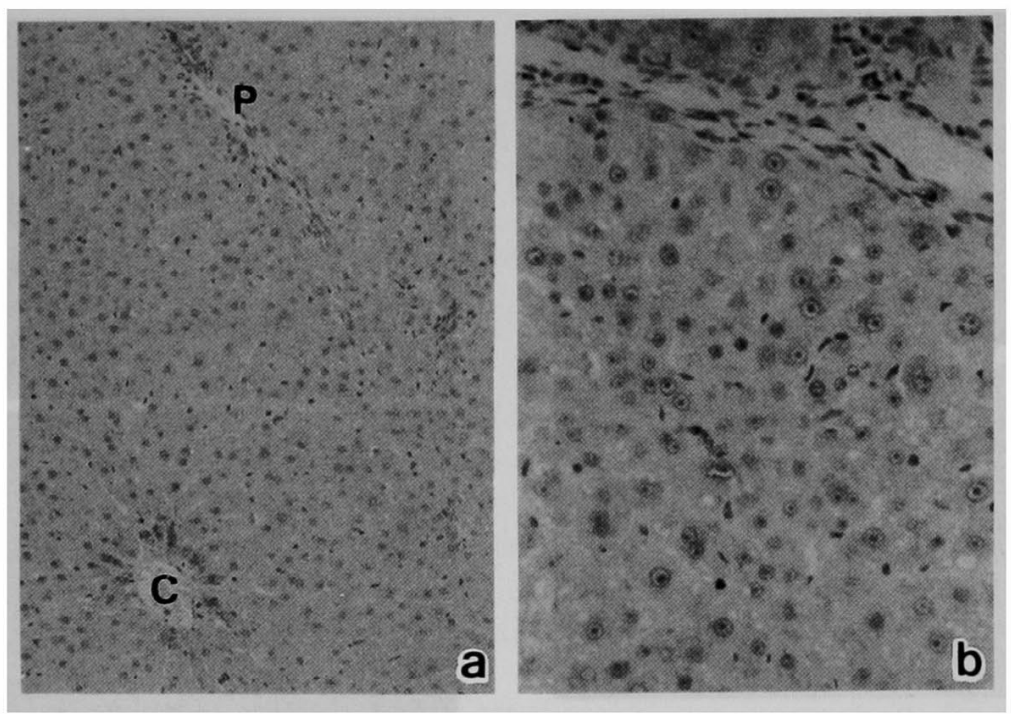

Fig. 7 Localization of EGF positive hepatocytes 24 hours after partial hepatectomy. a : Normal liver. EGF positive hepatoctes localized around central zone. $(\times 25)$ b: Cirrhotic liver. EGF positive hepatocytes were irregularly detected in pseudolobules. $(\times 50)$

硬変肝の切除標本にも局在を認めなかった，肝切 1 時問後より偽小葉内に不均一に局在を認めるようにな $ク ， 24$ 時間後まで暫増したが，局在を認めない肝細胞 が多数混在していた。 しかし 7 日以後には認められな くなった (Fig. 7b).

$\mathrm{TGF} \beta 1$ : 正常肝の切除標本には局在を認めなかっ た. 1 時間後にはほとんど局在が認められなかったか， 12時間後には門脈域に局在がみられ，24時間後には小 莱中心部にその局在をみとめ(Fig. 8a)，3 日後には局 在は認められなかった。

硬变肝の切除標本では偽小葉内肝細胞に不均一に TGF $\beta 1$ の局在が認められていた (Fig. 8b)。 そして肝 切後徐々に増加し24時間後には偽小葉全体にその局在 を認めた，3 日以後には減少をみとめるものの実駼終 了の 5 週間後をで咸小葉内の肝細胞にその局在が認め られた（Fig. 8c).

\section{4. 細胞外基質の局在}

切除標本：線維化巣には I ・III型コラーダンの局在 分布がみられ，特に型コラーダンが増加していた。 しかしフィブロネクチンの局在は軽微であった. ラミ ニンは線維化巣内の脈管の基底膜上に局在していた。

摘出標本：以上のコラーゲン・フィブロネクチン・ ラミニンの局在には肝切時の切除標本と比較して差異 はみられなかった（Fig. 9).

\section{考察}

臨床的に肝臟の部分切除が施行される肝硬変症の合 併をみる肝癌例の多くには，術後の肝再生があまり期 待が出来ないという理由で切除範囲が厳しく制約され ているのが現状である。 そしてこのような問題に対応 した硬变肝の肝再生の機序解明に関する研究 ${ }^{15)}$ 少な い. 特に肝細胞の分裂・增殖が正常肝之同様の機序で 起こるのか，また他の類洞壁細胞の分裂・増殂はどの ような状態なのか、そして線維化の程度に切除術前後 で差異がみられるのか等についても充分に解明されて いない。これまでには肝部分切除の約24時間後に $\mathrm{BrdU}$ の摄取率が著明に上昇することが報告さ $れ^{14,15)}$, 術後非常に早期に肝細胞の分裂・増殖の基盤が 完成することが明らかにされている

著者らが用いた TAA 投与によるラット肝硬変モデ ルは四塩化炭素モデルに比較して形態的にはヒト乙型 肝硬変症に類似している ${ }^{12,16)}$. 本剂投与による肝細胞 障害は四塩化炭素モデルのような過酸化脂質の関与は なく，細胞膜の直接的な障害に加え，RNA の代謝障害 やミトコンドリアの障害が基盤にみられ, 線維化は肝 細胞壊死後にみられる ${ }^{12,17), 18)}$. 今回用いたKasahara の方法では TAA の週 3 回の腹腔内投与にて死亡例は ほとんどなく， 3 週後に最も著明な絧胞障害を認め， 7 週後にはほほ例外なく偽小葉の形成がみられ全例に 

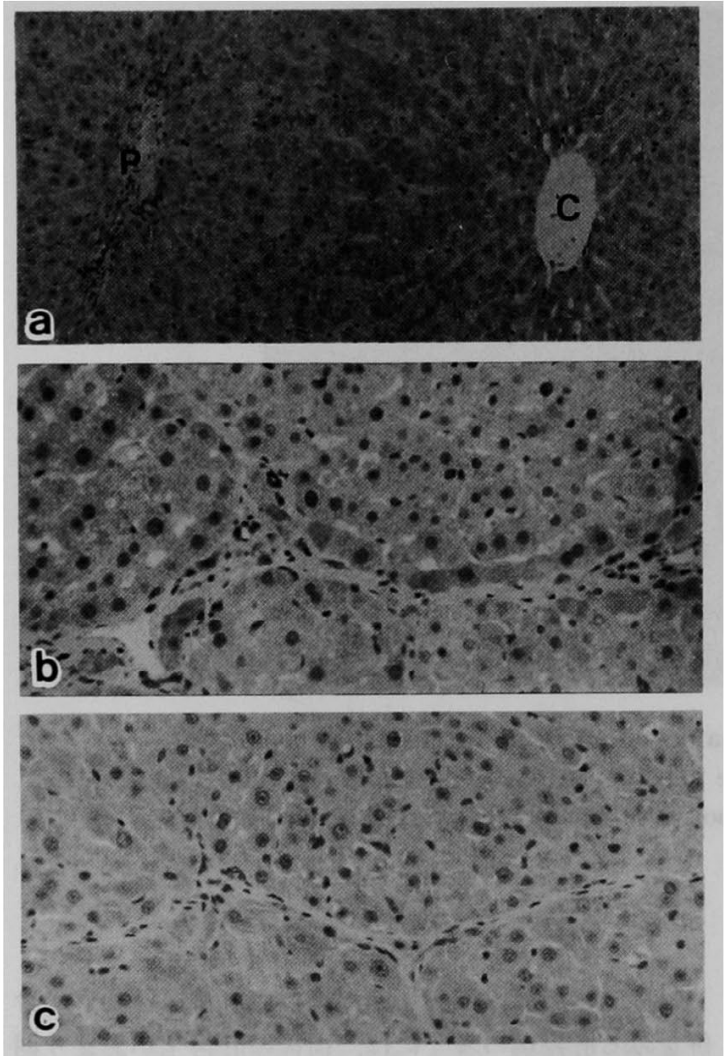

Fig. 8 Localization of TGF $\beta 1$ positive hepatocytes. a : Normal liver 24 hours after hepatectomy. A large number of TGF $\beta 1$ positive hepatocytes were localized in central and middle zone. b: Resected cirrhotic liver. TGF $\beta 1$ was irregularly detected in hepatocytes. $\mathrm{c}$ : Cirrhotic liver 7 days after partial hepatectomy. TGF $\beta 1$ positive hepatocytes localized in pseudolobules. (a $\times 25$, b \& $c \times 50)$

肝硬変の存在が観察された。特に薬剤の影響を取り除 くために 5 週間の休薬期間をおいたことで胆管や毛細 血管の増生は少なく, 線維性隔壁には膠原線維と線維 芽細胞の増殖がみられヒトの乙型肝硬変症により類似 した形態を示していた。

著者は硬変肝の肝細胞, 類洞壁細胞の動態を BrdU の摂取率を指標にして検討した。 その結果広範团切除 時の肝細胞の分裂・増殖をみると S 期細胞は術後 6 時 間後に一過性に減少するが，24時間後には急激に増加 し，72時間後にはほぼ術前の状態に戻ることが確認さ れ, 分裂・増殖の経時的增減は正常肝に類似していた。 しかし LIは24時間後の最も高い值で比較すると正常
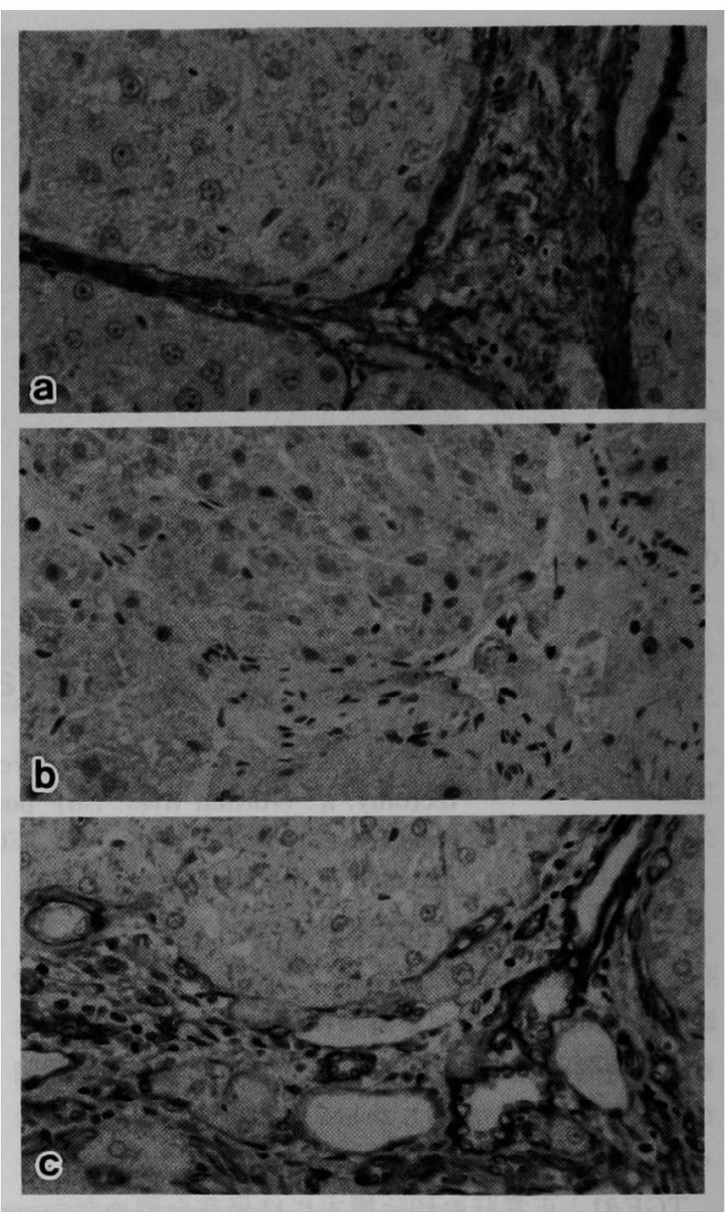

Fig. 9 Localization of extra-cellular matrices 5 weeks after partial hepatectomy. a: Type III collagen. $b$ : Fibronctine. $\mathrm{c}$ : Laminine $(\times 100)$

肝の $22.0 \%$ に対し，硬变肝では $12.3 \%$ と約 2 分の 1 に 減少していた，既に硬変肝では大きさおよび重量が減 少している上に，実質が線維成分により置換され，肝 細胞の絶対数が减少していることと考え合わせると, 肝細胞の LI の低下は分裂・増殖する肝細胞の数が極 端に減少していることを裏付けている。この結果は硬 変肝においては正常肝の術後にみられるよらな旺盛な 肝細胞の分裂・増殖があまり期待できないことを示唆 している.

一方正常肝の肝小葉においては BrdUの摂取がみ られる S 期肝細胞は門脈域に多数認められ，LIは 37.5\%に達していた。 これに比較して中心静脈域の LI

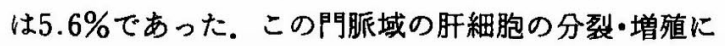
はなんらかの血行動態が関与している可能性が示唆さ 
れる. そしてこの血行動態と関連して HGF, bFGF， EGFの肝再生に批りる役割が注目される。松田らは肝 臓内の Kupffer 細胞等で産生される HGF が paracrine mechanismにより肝細胞に働くよりも, 脾, 肺 および腎で産生された HGF が endocrine mechanism により肝細胞の分裂・增殖に関与している可能性を指 摘している2). また, bFGF は細胞周期の $\mathrm{G}_{0}$ 期から $\mathrm{G}_{1}$ 期の移行にかけて必要なコンピーテンス因子として知

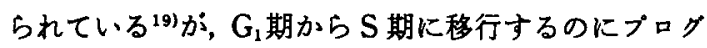
レッション因子も必要であり, HGF との関連で細胞 周期が進むことが考えられる、これを考虑すると著者 らが镅察した正常肝の BrdU 摄取 S 期肝細胞が門脈 域に遍在する分布はこの endocrine mechanism²)を間 接的に支持しているかむしれない。

一方硬変肝において偽小葉の辺縁部と中心部とでは 正常䀒にみられたよらな盖翼が存在しなくなってい る.ささらに溈小葉全体としてのLIの低下がみられた。 TAA ラット肝硬変モデルでもヒト肝硬変症と同様な 肝血行動態の変化が認められ 著しいとされる20).このことから硬変肝の S 期肝細 胞, $\mathrm{bFGF} \cdot \mathrm{EGF}$ 陽性肝細胞の局在の变化は肝偽小葉 内における循環動態の变化に依存している可能性が考 えられる。また門脈一体循環シャントや脾機能の変化 による増殖因子の肝内濃度の低下に加えて, 動静脈 シャントや門脈一体循環シャントに上る有効な増殖因 子の低下や酸素分圧の低下等の関与も考克られる。

$\mathrm{TGF} \beta 1$ 1は $\mathrm{G}_{1}$ 期から $\mathrm{S}$ 期へと移行をおさえる $\mathrm{Rb}$ タ ンパクのリン酸化を阻害し細胞分裂を抑制するといら 報告や HGF の作用を阻害するという報告があり，肝 細胞增殖抑制因子として既に知られている7，正常肝 でTGF $\beta 1 か ゙$ 肝切除後門脈域より中心静脈域へ局在が 移行する変化はJirtle らの報告6) と一致し，やはり血 行動態が関与していることる示唆している. 一方硬変 肝における TGF $\beta 1$ の局在は再生期においても持続的 にみられた。この観察結果から硬変肝の再生能低下に は TGF $\beta 1 か ゙$ 関与している可能性が高いと考えられ る7). 以上の結果から硬変肝では血行動態の变化に上 る bFGF, EGF, HGF 等の增殖因子の非効率的な供給 に加えてTGF $\beta 1$ 等の增殖抑制因子が存在するために 再生能が低下していることが推測される。これらの観 察結果よりみると肝切除術後の管理には特に血行動態 の安定化と,さらに HGF, EGF 等の增殖因子に加えて 抗 TGF $\beta$ 用の投与の可能性の検討が必要ではないか と思われる。
一方，類洞壁細胞は Kupffer 細胞、脂肪摂取細胞, 内皮細胞衫よび pit 細胞より構成され，それぞれ別々 の調節機構にもとつき分裂・增殖が行われていると考 えられているが9，BrdU 染色切片でニ上らの行った類 洞壁細胞を一括してLIを算出する方法を用いた ${ }^{14)}$.こ の結果と H.E 染色の観察とを対比すると LIはこうし た類洞壁細胞全ての動態を示するのではなく，Kupffer 細胞の増殖を中心にとらえている可能性が高いと 考えられる。これより類洞壁細胞の分裂・增殖につい てLIをみると肝切当日に最低值を示すが， 3 日後に は最高值となった。このような経時的增隇パーンは 硬変肝と正常肝で共通の変化であった。特に肝細胞之 の関連では肝細胞の LI が最高值を示す 2 日後に類洞 壁細胞の增殖す最も顕著となることが重要な知見と思 われた. Matsumotoらによると肝の HGFの 2 度目の ビークは肝切除後24時間以後で, この時期の HGF は 類洞壁細胞が合成すると考えられ"1), HGF 合成終了後 には肝細胞からのフィードヘック等の機転が働き，分 裂・增殖を始めるのではないかと思われる，そして全 期間を通して硬変肝の LI が約 $1 \%$ 高い値を示してい たが、TGF $\beta 1 か ゙$ 肝硬变症において持続的に高值を示す ことと合わせ TGF $\beta 1 か ゙$ 持続的に肝細胞に認められる ことから, TGF $\beta 1$ が類洞壁細胞に作用している可能性 む考えられる7. 将来的には類洞壁細胞に対しての TGF 1 1をはじめをすサイトカインの働きが問題と なってくると思われる。

また，線維化巣の細胞の分裂・増殖については病巣 には胆管細胞, 血管内皮細胞, 線維芽細胞等の間葉系 細胞がふくまれているが，これらの細胞の肝切除後の 增殖能には大きな变化はみられず，肝細胞の再生とは 直接的な関連がないことが示唆された。

細胞外基質の变化については TAA 投与開始後の線 維形成過程においてはフィブロネクチン，I・III型コ ラーゲンが增加し線維化を促進する. TAA 投与終了 後 7 週間経過を追った著者らの実験ではフィブロネク チンは次第に消退し線維中隔は細くなり，I・III型コ ラーゲンも减少した。このような線維化の消退期に行 われた肝切除術であるが，細胞外基質の局在には大き な変化が認められなかった。これは線維芽細胞の增殖 因子として働き，細胞外細胞外基質の蓄積を促進する

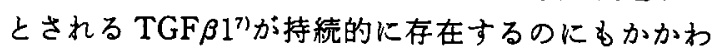
らず，細胞外基質の産生を担当する線維化巣の細胞の 細胞周期に大きな变化がなかったことと対応する結果 と思われた。肝切を契機として線維化が早期に急激に 
進行しないことは生体にとって望ましいことと思われ る. ᄂかし肝切除 5 週後でしか子 TAA 投与終了後 10 週も経過しているにもかかわらず，切除標本と同程度 の線維化像が認められたことは肝切除後において細胞 外基質の代謝も一時的に抑制されている可能性が考え られる。

稿を終えるにあたり，貴重な標本の作成に御協力いただ きむした日本医科大学第 2 外科教室の諸先生に謝意を表し ます。また，本研究の遂行に多大な御援助を下さいました日 本医科大学第 2 病理教室技術員各位にたいして厚く御礼申 し上げます。

\section{文献}

1) Matsumoto $K$, Nakamura $T$ : Roles of HGF as a pleiotropic factor in organ regeneration. EXS $65: 225-249,1993$

2）松田康伸，中村敏一：肝細胞增殖因子(HGF) の 分子生物学. 日本臨床 $51: 435-445,1993$

3) Stromblad S, Andersson G: The coupling between transforming growth factor- $\alpha$ and the epidermal growth factor receptor during rat liver regeneration. Experi Cell Res 204: 321 $-328,1993$

4) Presta M, Statuo M, Rusnati M, et al : Characterization of a $\mathrm{Mr} 25,000$ basic fibroblast growth factor form in adult, regenerating, and fetal rat liver. Biochem Biophys Res Commu 164: 1182 $-1189,1989$

5) Gokcora N, Gundogdu S, Aricioglu A, et al: The effect of epidermal growth factor on liver lipid peroxidation and glutathione levels in lobectomized rats. Biochem Cell Biol 70:259 $-262,1991$

6) Jirtle RL, Carr BI, Scott CD : Modulation of insullin-like growth factor-II/mannose 6phosphate receptors and transforming growth factor-beta 1 during liver regeneration. J Biol Chem 266: 22444-22450, 1991

7）松本邦夫, 中村敏一: 肝再生, 肝の線維化 TGF $\beta$. 実験医学 $10: 1892-1897,1992$

8) Gohda E, Matsunaga $T$, Kataoka $\mathrm{H}$, et al:
TGF-bata is a potent inhibitor of hepatocyte growth factor secretion by human fibroblasts. Cell Biol Int Rep 16: 917-926, 1992

9）坂本俊樹, 庄司 佑, 横室公三：肝再生之類洞壁細 胞. 肝胆脺 $24: 959-969,1992$

10) Higgins GM, Anderson RM : Experimental pathology of the liver; I. Restoration of the liver of the white rat following partial surgical removal. Arch Pathol 12 : 186-202, 1931

11) Kasahara $Y$ : Spleno-hepatoplasty in rats with chemically-induced cirrhosis of the liver. Arch Jap Cin $46: 335-360,1977$

12）澤美彦，岡上 武，伊藤義人，他：肝硬変の肝血 行動態の研究一thioacetamide によるラット肝硬 変モデルを用いた検討. 肝䁍 31：1064-1069， 1990

13）高橋 学，佐↔木功典，村上知之：Bromodeoxyuridine 標識に上る細胞動熊の解析。最新医学 $40: 80-84,1985$

14）二上玲子：ラット肝の部分切除後の肝再生過程に 括ける肝小葉の経時的変化一主として血管注入法 に上る倹討一。肝䁍 $32: 127-138,1992$

15）察 栄若, 山下隆史, 芳野裕明，他：障害肝におけ る肝切除の 1 核，2 核肝細胞の細胞動態に関する 㛟討。肝葴 $30: 1702-1707,1989$

16) Dashti H, Jappson B, Hagestrand I, et al: Thioacetamide- and Carbon tetrachloride induced liver cirrhosis. Eur Surg Res 21 : 83-91, 1989

17) Nurber R, Teutsch HF, Sasse D: Methabolic zonation in thioacetamide-induced liver cirrhosis. Histochemistry $69: 277-288,1980$

18) Gabriel LP: Toxic responses of the liver. In : Toxcology, Edited by CD Klassen, MO Amdur, J Doull. Macmillan Publishung Company, New York, 1989, p286

19）二陛堂敏雄：サイクリンによる細胞周期調節。 CRC 2: 80-90, 1993.

20）三枝 信, 渡辺清治, 奥平雅彦, 他：実験的肝硬变 における肝内微小血管の变化，とくに偽小葉結節 の形成・增大過程に捛ける䀒動脈の意義について の恰討一. 肝缄 $32: 708-715,1991$ 


\title{
Histopathological study of regenerative mechanism after partial hepatectomy of the liver cirrhosis induced by thioacetamide administration
}

\begin{abstract}
Masataka INOKUCHI ${ }^{* * *}$, Tetsuo SHIBUYA, Tasuku ShoJI* and Goro AsANo**
This study was designed to elucidate actual regeneration process after $70 \%$ hepatectomy of cirrhotic liver induced by intra-peritoneal administration of $4 \%$-thioacetamide for 7 weeks in rats. Cellular kinetics were analyzed by BrdU labeling-index (LI). LI showed maximum point $12.3 \pm 1.7 \%$ in hepatocytes of cirrhotic-liver (LC), at 24 hours after hepatectomy compared with $22.0 \pm 3.0 \%$ in non-cirrhotic liver. Basic-FGF and EGF irregularly loclized in hepatocytes of LC at 24 hours after the operation. TGF $\beta 1$ were continuously detected in hepatocytes of LC from pre-operative state to 5 weeks after hepatectomy. These results suggest that the regenerative potentiality of hepatocytes are reduced due to the inefficiency of growth factors and the inhibition by TGF $\beta 1$.
\end{abstract}

* Second Department of Surgery, Nippon Medical School (Tokyo)

** Department of Pathology, Nippon Medical School (Tokyo) 